\title{
Model Pembelajaran Bamboo Dancing dengan Pendekatan CTL
}

\author{
Vina Ruliyanti ${ }^{1)}$, Siti Rahayu' ${ }^{2}$, \\ 1),2) Universitas Muhammadiyah Pringsewu Lampung \\ sitirahayu@umpri.ac.id
}

\begin{abstract}
Abstrak
Tujuan dari penelitian untuk mengetahui rata-rata hasil belajar matematika siswa yang diperoleh melalui model pembelajaran bamboo dancing menggunakan pendekatan CTL lebih baik dari pada rata-rata hasil belajar matematika siswa yang diperoleh melalui model pembelajaran bamboo dancing. Populasi dalam penelitian ini adalah seluruh siswa kelas VIII MTs Islamiyah Sukoharjo. Instrumen penelitian berupa tes uraian. Analisis data menggunakan uji-t dengan prasyarat uji normalitas dan uji homogenitas. Berdasarkan analisis data disimpulkan bahwa rata-rata hasil belajar matematika menggunakan model pembelajaran bamboo dancing dengan pendekatan CTL lebih baik dari pada rata-rata hasil belajar matematika yang diperoleh melalui model pembelajaran bamboo dancing tanpa menggunakan pendekatan CTL.
\end{abstract}

Kata kunci :bangun ruang sisi datar,bamboo dancing, CTL

\section{PENDAHULUAN}

Matematika merupakan ilmu universal yang mendasari perkembangan teknologi modern, mempunyai peran penting dalam berbagai kehidupan. Matematika juga merupakan salah satu bidang studi yang menduduki peranan penting dalam dunia pendidikan. Sebagai bukti adalah pelajaran matematika diberikan kepada semua jenjang pendidikan mulai dari sekolah dasar sampai perguruan tinggi. Peranan matematika terhadap perkembangan sains dan teknologi sudah jelas, bahkan bisa dikatakan bahwa tanpa matematika sains dan teknologi tidak akan dapat berkembang. Matematika tidak hanya sekedar menghafal tetapi dibutuhkan pengertian dan pemahaman sehingga dapat menghasilkan pembelajaran yang bermakna. 
Pelaksanaan pembelajaran matematika diperlukan perencanaan dan persiapan yang matang agar dapat berhasil dengan baik. Untuk itu guru harus menerapkan berbagai model pembelajaran yang sesuai dengan materi pelajaran agar matematika menjadi salah satu mata pelajaran yang menyenangkan bagi siswa, sehingga konsep-konsep matematika bisa dikuasai oleh siswa secara optimal. Seorang guru harus bisa memilih model pembelajaran yang bisa mengaktifkan siswa untuk menghubungkan materi pembelajaran dengan kehidupan sehari-hari, maka dari itu siswa bisa menjadi lebih aktif dan lebih semangat dalam proses pembelajaran karena mereka berpikir bahwa pembelajarannya bermakna untuk diterapkan dalam kehidupan sehari-hari, dan pasti mereka berpikir bahwa proses pembelajaran yang selama ini dilakukan tidak sia-sia.

Pemilihan dan penggunaan model yang kurang efektif akan berdampak pada siswa dalam menguasai konsep-konsep matematika. Selain itu proses pembelajaran ditandai dengan adanya beberapa unsur antara lain seperti tujuan, bahan, alat, model, dan pendekatan, serta evaluasi. Unsur tersebut berfungsi sebagai cara atau teknik untuk mengantarkan bahan pelajaran agar sampai kepada tujuan. Dalam pencapaian tujuan tersebut, model pembelajaran sangat penting sebab dengan adanya model pembelajaran, bahan ajar dapat dengan mudah dipahami oleh siswa.

Berdasarkan hasil observasi yang penulis lakukan di MTs Islamiyah Sukoharjo III melalui pengamatan dan wawancara kepada guru kelas VIII diperoleh informasi bahwa proses pembelajaran di MTs Islamiyah Sukoharjo III guru telah menggunakan model pembelajaran Bamboo Dancing. Penyampaian materi yang kurang maksimal membuat hasil belajar siswa rendah.Selain itu, didapatkan informasi jika hasil belajar siswa masih rendah dalam pelajaran matematika pada materi Bangun Ruang Sisi Datar.

Berdasarkan data hasil ulangan harian semester genap bahwa dari 103 siswa kelas VIII, dengan materi bangun ruang sisi datar diperoleh hanya 20,39\% atau 21 siswa yang memperoleh nilai minimal 75 . Sedangkan $79,61 \%$ atau 82 siswa memperoleh nilai kurang dari 75 , dengan demikian maka pembelajaran dapat dikatakan belum mencapai ketuntasan hasil belajar.

Rendahnya hasil belajar matematika siswa tersebut diduga penerapan pembelajaran dikelas hanya terpaku pada buku yang bersifat abstrak atau hanya bersifat teori-teori, contoh soal yang diberikan oleh guru tersebut juga kurang berkaitan dengan kehidupan sehari-hari mereka sehingga susah diingat dan dipahami oleh siswa. Hal ini membuat siswa kurang termotivasi belajar, jika siswa kurang termotivasi untuk belajar maka akan berdampak pada kesulitan siswa dalam menguasai konsep materi pelajaran dan menyebabkan hasil belajar menjadi rendah. Padahal pembelajaran akan lebih menyenangkan dan dapat menimbulkan motivasi belajar siswa apabila siswa mengaitkan pembelajaran yang dipelajari dikelas dalam kehidupannya sehari-hari. 
Untuk mengatasi masalah tersebut Salah satu pendekatan yang dapat membantu guru yaitu pendekatan CTL. Pendekatan CTL merupakan suatu konsepsi yang membantu guru mengaitkan konten mata pelajaran dengan situasi dunia nyata dan memotivasi siswa membuat hubungan antara pengetahuan dan penerapanya dalam kehidupan mereka, pembelajaran CTL merupakan pembelajaran yang memungkinkan siswa untuk menguatkan, memperluas, menerapkan pengetahuan dan ketrampilan akademik mereka dalam berbagai macam tatanan dalam sekolah dan luar sekolah agar dapat memecahkan masalahmasalah dunia nyata atau masalah-masalah yang disimulasikan. Pembelajaran CTL terjadi apabila siswa menerapkan dan mengalami apa yang sedang diajarkan dengan mengacu pada masalah-masalah kehidupan sehari-hari (Trianto 2011:103). Sehingga dengan penerapan model pembelajaran Bamboo Dancing dengan pendekatan CTL diharapkan siswa akan lebih temotivasi untuk belajar dan diharapkan hasil belajar siswa menjadi lebih tinggi.

\section{METODE PENELITIAN}

Penelitian ini menggunakan jenis penelitian kuantitatif yang dilaksanakan di MTs. Islamiyah Sukoharjo III, populasi dalam penelitian ini seluruh siswa kelas VIII MTs Islamiyah Sukoharjo semester genap tahun ajaran 2018-2019 dengan jumlah siswa 76 siswa yang terbagi ke dalam 3 kelas dan sampel sebanyak dua kelas sebagai kelompok eksperimen dan kelompok kontrol dengan menggunakan teknik cluster random sampling, karena populasi terbagi dalam kelas-kelas yang memiliki karakter yang sama. Sedangkan penentuan sampel dengan cara sistem undian VIII B sebagai kelas kontrol dan kelas VIII A sebagai kelas eksperimen. Sebelum tes dilakukan kepada kelas eksperimen dan kelas kontrol, maka diambil 10 peserta didik dari populasi diluar kelas eksperimen dan kelas kontrol sebagai sampel uji coba untuk melihat validitas dan reliabilitas. Penelitian terdiri dari satu variabel yaitu hasil belajar. kemudian pengembangan instrumen dilakukan dengan cara validitas, realibilitas, tingkat kesukaran dan daya pembeda hal ini sebagaimana yang dinyatakan oleh Sumarna Supranata (2009).

Teknik pengumpulan data dalam penelitian ini menggunakan tes tertulis yang bertujuan untuk memperoleh hasil belajar peserta didik. tes dilakukan pada kelas eksperimen dan kelas kontrol. Tes dalam penelitian ini berupa prites dan postes untuk mengetahui pemahaman peserta didik yang dilaksanakan sesudah dan sebelum pembelajaran. Instrumen tes yang digunakan berbentuk tes uraian yang dibuat sama untuk kelas eksperimen dan kelas kontrol. Soal sebanyak 4 item dengan skor maksimum 100 minimun 0.

Adapun teknik analisis data yang digunakan yaitu pengujian hipotesis dan menjawab rumusan masalah yang diajukan, pengujian hipotesis dalam penelitian ini menggunakan statistik uji-t. Sebelum melakukan pengujian hipotesis dengan menggunakan uji-t, maka terlebih dahulu dua asumsi dasar harus dipenuhi yaitu uji normalitas dan homogenitas data. Jika data tersebut tidak berdistribusi 
normal maka pengujian hipotesis dilakukan dengan statistik nonparametrik menggunakan uji Mann- Whitney U-Test.

\section{HASIL DAN PEMBAHASAN}

Hasil uji coba instrmen menunjukan bahwa instrument tes yang digunakan adalah instrumen yang valid dan variabel dengan tingkat kesukaran yaitu sedang dan daya pembeda yang sangat baik. Data hasil belajar siswa adalah data yang berdistribusi normal dan berasal dari data yang bersifat homogen, maka dilanjutkan pengujian hipotesis penelitian.

Berdasarkan hasil penelitian pada kelas eksperimen didapat $\mathrm{t}$ hitung $=3,295$ lebih dari t tabel $=2,0126$ ini menunjukan hasil belajar matematika pada siswa kelas eksperimen lebih baik daripada hasil belajar siswa kelas control. Hal ini menunjukan bahwa pembelajaran menggunakan model pembelajaran bamboo dancing dengan pendekatan CTL lebih baik daripada pembelajaran dengan model pembelajaran bamboo dancing tanpa menggunakan pendekatan CTL. Dalam model pembelajaran bamboo dancing dengan pendekatan CTL siswa diatur secara berkelompok, dan pembelajaranya dikaitkan dengan kehidupan sehari-hari siswa, sehingga siswa lebih bersemangat belajar dan lebih mudah memahami materi yang sedang dipelajari. Ini terbukti pada kegiatan pembelajaran saat kelompok berdiskusi, mereka lebih cepat memahami konsep-konsep yang ada didalam buku dengan melihat langsung bentuk-bentuk bangun ruang kubus dan balok yang ada disekitar mereka dan dapat dilihat dari hasil belajar siswa yang menggunakan model pembelajaran bamboo dancing dengan pendekatan CTL lebih baik daripada menggunakan model pembelajaran bamboo dancing tanpa menggunakan pendekatan CTL. Hal ini sebagaimana dinyatakan Karunia dan Ridwan (2015: 39) pendekatan CTL merupakan "konsep belajar yang membantu guru mengaitkan antara materi yang diajarkan dengan situasi dunia nyata siswa dan mendorong siswa membuat hubungan antara pengetahuan yang dimilikinya dan penerapan dalam kehidupan sehari-hari”.

Penerapan model pembelajaran Bamboo Dancing dengan pendekatan CTL pada kelas eksperimen juga terbukti sangat membantu siswa dalam memahami konsep-konsep yang masih abstrak. Hal ini terlihat saat proses pembelajaran di kelas eksperimen siswa lebih mudah memahami materi dan siswa lebih aktif serta tertarik untuk belajar. Selain itu, hasil belajar berdasarkan tes penilaian hasil belajar matematika yang peneliti lakukan juga menunjukkan adanya perbedaan rata-rata hasil belajar siswa kelas eksperimen lebih baik dibandingkan dengan rata-rata pada kelas kontrol. Hal ini sesuai dengan hasil dari penelitian Kurniati

dkk (2015) bahwa penggunaan pembelajaran $C T L$ memberikan nilai rata-rata kelompok siswa lebih baik. 


\section{SIMPULAN}

Berdasarkan analisis data penelitian ini dapat didimpulkan bahwa pembelajaran dengan menerapkan model pembelajaran Bamboo Dancing dengan pendekatan CTL memberikan hasil belajar yang baik jika dibandingkan dengan pembelajaran Bamboo Dancing tanpa menggunakan pendekatan CTL.

\section{DAFTAR PUSTAKA}

Karunia, M Ridwan. (2015). Penelitian Pendidikan Matematika. Bandung: PT Rafika Aditama.

Kurniati dkk. (2015). "Matematical Critical Thinking Ability Through Contextual Teaching and Learning Aproach". IndoMS-JME, volume 6. no 1.

Sumarna Surapranata. (2009). Analisis, Validitas, Reliabilitas dan Interprestasi Hasil Tes Implementasi Kurikulum 2004. Bandung: PT Remaja Rosdakarya.

Trianto. (2011). Mendesain Model Pembelajaran Inovatif - Progresif. Jakarta : Prenada Gorup. 